\title{
Analisis Kesulitan Proses Pembelajaran Berbasis Hots di Kelas VSDN 4 Muara Padang
}

\author{
Berlian Arista Putri ${ }^{1}$, Fuaddilah Ali Sofyan ${ }^{2}$ \\ ${ }^{1}$ Program Studi Pendidikan Guru Madrasab Ibtidaiyah, Universitas Islam Negeri \\ Raden Fatah Palembang \\ ${ }^{2}$ Fakultas Ilmu Tarbiyah Dan Keguruan, Pendidikan Guru Madarasab Ibtidaiyah, Universitas Islam Raden \\ Fatah Palembang \\ e-mail: berlianaristaputri@gmail.com
}

\begin{abstract}
One of the elements of the 2013 curriculum transformation at the elementary school level is the strengthening of the learning process and the application of thematic integration by using a scientific and familiar approach with high-level thinking skills (HOTS) for students. This study aims to determine how the implementation of HOTS assessments, as well as the advantages and obstacles of implementing HOTS assessments in thematic learning. This study uses qualitative methods, with data collection techniques used observation and interviews. From the results of this study it can be seen that. (1) teachers compile their own RPP, (2) the implementation of HOTS-based learning that is already running, (2) learning assessment is not entirely based on the 2013 curriculum, (4) there are some obstacles when implementing HOTS-based learning in class V SDN 4 Muara Padang. Therefore there is still a lot of improvement to the HOTSbased learning process at SDN 4 MuaraPadang, this problem exists because schools have just shifted from the 2006 curriculum to the 2013 curriculum which is more dominant in HOTS learning.
\end{abstract}

Kata kunci: learning HOTS, elementary school students, learning constraints.

\section{PENDAHULUAN}

Manusia adalah makhluk berfikir. Segala tindakan yang dilakukan diawali dengan cara berfikir terlebih dahulu. Apakah proses berfikir itu termasuk sederhana atau kompleks. Kemampuan berfikir manusia juga yang membedakan manusia dengan makhluk lainnya. Dengan kemampuan berfikirnya manusia dapat menghasilkan temuantemuan yang dapat memberikan manfaat bagi dunia. Cara berfikir seseorang dipengaruhi oleh pendidikan yang di dapat oleh seseorang. Karena pada dasarnya pendidikan adalah upaya untuk memberikan pengetahuan, wawasan, keterampilan dan keahlian tertentu kepada setiap manusia unytuk mengembangkan bakat dan kepribadian mereka, agar mampu menghadapi setiap perubahan yang terjadi akibat kemajuan ilmu pengetahuan dan teknologi. Selain itu pendidikan juga merupakan sarana untuk meningkatkan sumber daya manusia karena merupakan salah satu dari program pembangunan di Indonesia yang harus di tempuh oleh lapisan masyarakat (Wowo Sunaryo, 2001). 
Menurut Marpaung (1987: 46), berfikir merupakan proses yang terdiri atas penerimaan informasi dari dalam atau dari luar diri siswa, pengolaan, penyimpanan, dan pemanggilan kembali informasi itu dari ingatan siswa. Dengan kemampuan berfikirnya manusia dapat mengembangkan berbagai kemampuan. Pengomptimalan kemampuan yang kita miliki dapat dilakukan dengan mengoptimalkan kerja otak kanan dan otak kiri. Otak kanan berkaitan dengan pemikiran kreatif dan otak kiri berkaitan dengan kemampuan berfikir kritis. Kemampuan berfikir kritis dan kreatif merupakan perpaduan antara kerja otak kanan dan otak kiri. Selanjutnya keterampilan berfikir kritis dan kreatif dikategorikan sebagai keterampilan berfikir tingkat tinggi (Higher Order Thingking Skill).

Kurikulum 2013 yang diberlakukan saat ini mengamani penyempurnaan pada standar isi dan standar penilaian. Pada standar isi dirancang agar peserta didik mampu berfikir kritis dan analisis sesuai dengan standar internasional dengan melakukan pengurangan materi yang tidak relevan dan pendalaman serta peluasan materi yang relevan bagi peserta didik. Sedangkan pada standar penilaian dilakukan dengan mengadaptasikan model-model penilaian standar internasional bertahap. Penilaian hasil belajar lebih menitikberatkan pada kemampuan berpikir tingkat tinggi (Kemendikbud, 2017).

Namun, berdasarkan hasil pengamatan dan anlisis ketika siswa diberikan soal dari guru, cara berfikir siswa cenderung sama dengan contoh-contoh yang telah diberikan oleh guru. Tetapi pada saat sisa diberikan soal yang sedikit berbeda dengan contoh maka siswa akan merasa kesulitan. Pada kondisi yang demikian biasanya siswa hanya dituntut untuk menerima sesuatu yang dianggap penting dan menghafal. Cara berikir siswa yang sepeti ini menjadi lambat dan siswa hanya dapat menyelesaikan soal yang tergolong tingkat rendah.

Sedangkan pada perkembangan pendidikan di tingkat internasional Kurikulum 2013 dirancang dengan berbagai penyempurnaan. Penyempurnaan yang dilakukan, yaitu mengenai pendalaman dan perluasan materi, standar penilaian, dengan mengadaptasi secara bertahap model-model penilaian standar internasional. Penilaian hasil belajar diharapkan dapat membantu peserta didik dalam meningkatkan kemampuan berfikir tingkat tinggi HOTS, karena dengan berfikir tingkat tinggi dapat mendorong peserta didik untuk berfikir secara mendalam dan luas menganai materi pelajaran.HOTS atau keterampilan berfikir tinggi merupakan bagian dari taksonomi Bloom hasil revisi yang berupa kata kerja operasional yang terdiri dalam analye (C4), evaluate (C5), create (C6) yang dapat digunakan dalam penyusunan soal (Aydin \& Yilmaz. 2010:58).

SDN 4 Muara Padang merupakan salah satu SD Negeri sudah menggunakan kurikulum 2013. Proses pembelajarannya berbasis HOTS. Seluruh jenjang kelas sudah menggunakan kurikulum 2013 meski dalam pelaksanaannya belum terlalu maksimal.

Berdasarkan hasil wawancara bersama dengan guru kelas V SDN 4 Muara Padang pada hari rabu tanggal 25 september 2019, terkait proses pembelajaran berbasis HOTS dalam proses belajar mengajar yang dilaksanakan. Beliau menginformasikan bahwa sekolah telah menggunakan kurikulum 2013 sejak dua tahun yang lalu. Serta dalam pembelajaran yang digunakan sudah berbasis HOTS meski pada pelaksanaan pembelajarannya masih banyak kendala atau hambatan, namun dari pihak sekolah dan guru berusaha dengan baik agar pembelajaran berbasis HOTS dalam terlaksana dengan baik. Berdasarkan hal ini, peneliti melakukan observasi dan wawancara pada guru kelas $\mathrm{V}$ 
SDN 4 Muara Paadang, alasan peneliti memilih kelas tinggi karena pembelajaran berbasis HOTS adalah pembelajaran yang membutuhkan pemikiran yang tinggi.

Sebelum peneliti observasi, guru kelas memberikan RPP, yang selanjutnya menjadi acuan peneliti untuk meneliti apa saja yang ada di RPP untuk pembelajaran berbasis HOTS. Serta peneliti tertarik untuk melihat lebih jauh bagaimana proses pembelajaran berbasis HOTS. Secara Khusus, penelitian ini bertujuan untuk mengetahui apa komponen yang ada didalam RPP serta bagaimana proses pelaksanaannya didalam kelas, dan yang terakhir yaitu kendala atau hambatan yang timbul.

\section{METODOLOGI}

Penelitian ini menggunakan pendekatan kulaitatif yang merupakan suatu bentuk penelitian yang bersifat deskriptif kualitatif. Penelitian ini bertujuan untuk mendeskripsikan hasil pengolahan data yang berupa kata-kata, gambaran umum yang terjadi di lapangan. Penelitian kulaitatif digunakan untuk memahami realitas sosial, yaitu melihat dunia dari apa adanya, bukan dunia yang seharusnya. Penelitian kualitatif dilakukan pada kondisi alamiah dan bersifat penemuan (Arikunto 2006, Sugiyono, 2016). Dalam penelitian ini menggunakan teknik pengumpulan data dengan cara melakukan wawancar, dan observasi. Berikut ini kisi-kisi pertanyaan wawancara.

\section{Tabel 2. Daftar Pertanyaan WawancaraGuruKelas V SDN 4 Muara Padang}

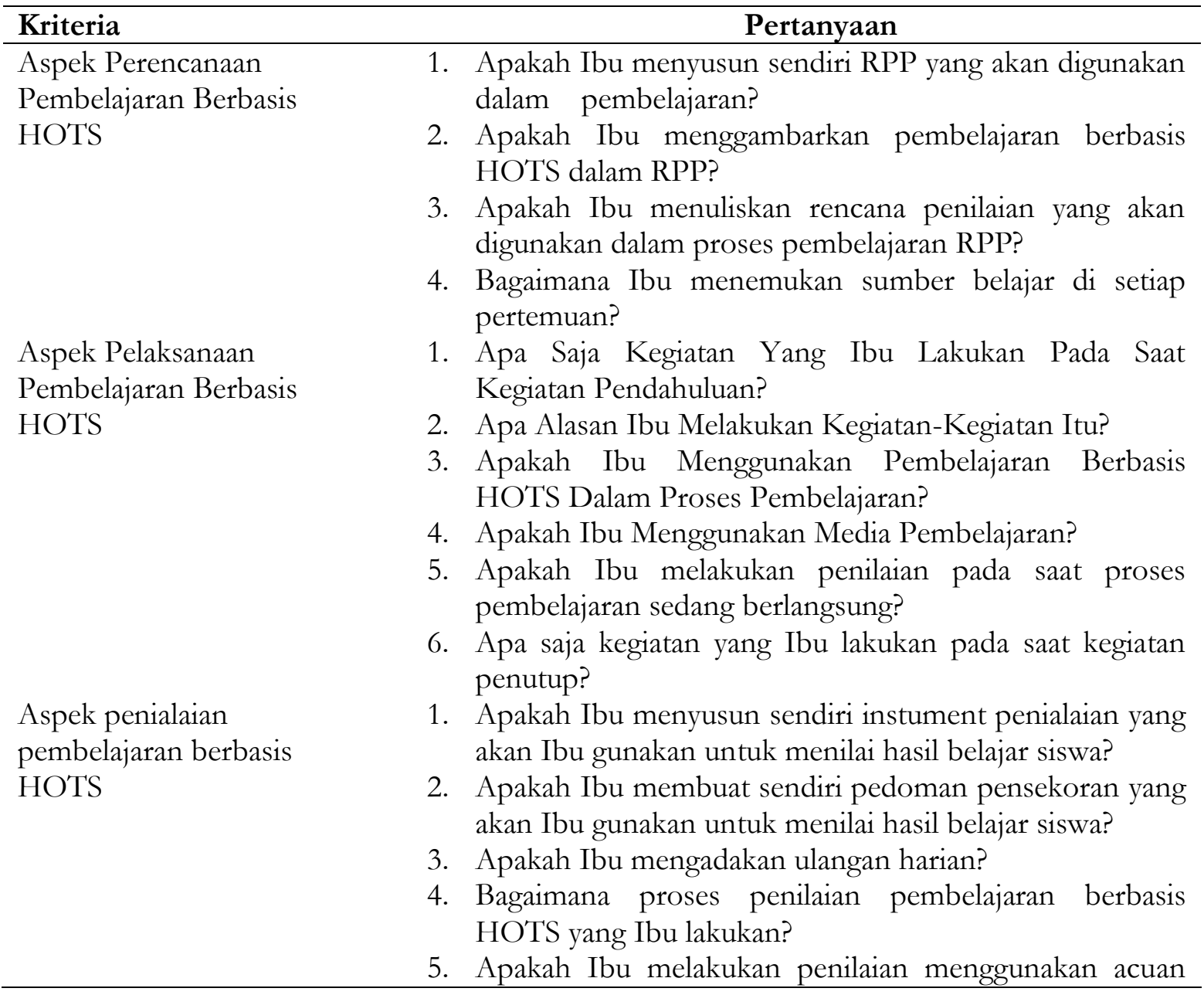


kriteria modus untuk penilaian sikap?

Sedangkan analisis data pada penelitian ini menggunakan analisis data wawancara dengan model Miles and Hubermen (1992). Miles and Hubermen terdiri dari tahapan penggolongan data/reduksi data, penyajian data, dan verivikasi data. Berikut gambara dari model Miles and Hubermen dalam penelitian kulalitatif.

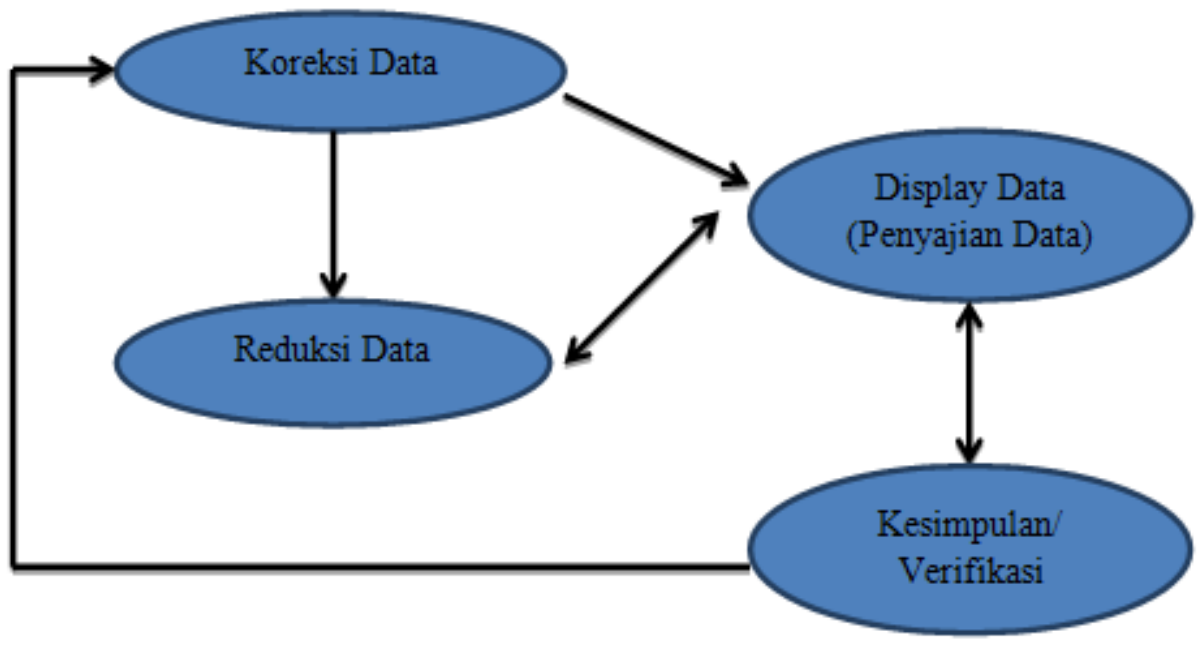

\section{Gambar 1. Analisis Data model Miles and Hubermen (1992)}

\section{HASIL DAN PEMBAHASAN}

\section{Hasil Penelitian}

Penelitian yang dilakukan peneliti tentang analisis pembelajaran berbasis HOTS pada peserta didik kelas 5 SDN 4 Muara Padang meliputi perencanaan pembelajaran, pelaksanaan pembelajaran, dan kendala yang dihadapi guru saat kegiatan belajar mengajar.Hasil penelitian yang dilakukan peneliti adalah sebagai berikut.

\section{Aspek Perencanaan Pembelajaran}

Berdasarkan wawancara, kegiatan perencanaan pembelajaran yang dilakukan oleh guru telah sesuai dengan RPP yang telah dibuat, yaitu dengan berpedoman pada kurikulum 2013.Hal ini sesuai dengan hasil wawancara peneliti dengan guru kelas V SDN 4 Muara Padang.

Peneliti :“Apakah Ibu menyusun sendiri RPP yang akan digunakan dalam pembelajaran?”

Guru

: "Iya, kami para guru diwajibkan oleh Kepala Sekolah menyusun RPP untuk pembelajaran yang akan kami lakukan di kelas."

Berdasarkan hasil Analisis RPP yang ditunjukkan kepada peneliti, RPP tersebut sudah mengarah kepada pembelajaran berbasis HOTS, karena terdapat beberapa point yang merujuk pada C4, C5, dan C6 yaitu mengenai kemampuan berfikir tingkat tinggi 
berdasarkan Taksonomi Bloom. Peneliti kembali mengajukkan pertanyaan terkait RPP yang ditunjukkan.Wawancaranya adalah sebagi berikut.

Peneliti : "Apakah Ibu melihat atau mencermati RPP, sebelum kegiatan belajar mengajar dilakukan?”

Guru

: "Tidak setiap hari, hanya pada materi-materi tertentu saja salah satunya yaitu pada pembelajaran soal-soal HOTS saja.

Berdasarkan hasil wawancara dengan kepala sekolah, peneliti menanyakkan mengenai kewajiban guru membuat sendiri RPP.Berikut ini catatan wawancara peneliti dengan kepa sekolah.

Peneliti : "Apakah benar guru di sekolah ini diwajibkan membuat RPP sendiri?"

Kepala sekolah : "Memang benar,tetapi boleh juga mendonlowad dari internet lalu di kembangkan karena sekolah ini baru sekitar dua tahun beralih dari KTSP 2006 ke Kurikulum 2013,".

Dari hasil wawancara dapat di analisis bawahsanya, kepala sekolah ingin membuat para guru menjadi berkreasi dengan menyusun RPP sendiri, meski para guru di perbolehkan mengambil dari internet tetapi harus dimodifikasi terlebih dahlu. Berikut ini adalah tabel komponen RPP yang ditunjukkan oleh Ibu Sri Astutik guru kelas V SDN 4 Muara Padang.

Selain data-data dari hasil wawancara terkait Rencana Pelaksanaan Pembelajaran, peneliti juga melakukan observasi pada komponen RPP yang digunakan berdasarkan Permendikbud No.22 Tahun 2016 tentang Standar Proses.berikut pemaparan hasilnya.

Tabel 3. Hasil Observasi Pada Komponen RPP

\begin{tabular}{ll}
\hline Komponen RPP & \multicolumn{1}{c}{ Keterangan } \\
\hline Identitas sekolah & Identitas sekolah dituliskan dengan \\
& mencantumkan nama satuan pendidikan yaitu \\
& SDN 4 Muara Padang. \\
Mata pelajaran & RPP yang ditunjukkan guru merupakan RPP \\
& yang sudah mengacu pada kurikulum 2013, \\
& dimana sudah ada tema, subtema, \\
& pembelajaran ke-berapa, dan juga alokasi \\
& waktu. \\
Kelas/semester & RPP ini diperuntukan untuk kelas V semester \\
Alokasi waktu & Alokasi waktu yang dicantumkan yaitu 6x35 \\
& menit (1 pertemuan).
\end{tabular}




Komponen RPP
Kompetensi inti
Kompetensi dasar
Indicator pencapain kompetensi

Materi pembelajaran

Kegiatan pendahuluan

Kegiatan inti

Kegiatan penutup

Penilaian, pembelajaran

Teknik penilaian

Instrumen penilaian
Pembelajaran remedial pengayaan

Media/alat, bahan, dan sumber belajar

Kompetensi inti ditulis lengkap mulai dari KI 1-4 pada seluruh RPP.

Kompetensi dasar disusun sesuai dengan mata pelajaran yang akan diajarkan pada hari itu, KD dijabarkan pada setiap mata pelajaran.

Penulisan isi indicator sudah ditulis setiap mata pelajaran, dan sudah dijabarkan ranah/keterampilan serta sudah terdapat penjabaran nilai kognitif, afektif dan psikomotorik.

Pada RPP sudah dicantumkan beberapa materi tetapi poin-poinnya saja. Penulisan materi mengacu pada buku guru dan juga buku siswa.

Kegiatan pembelajaran

Pada kegiatan pendahuluan tercantum adanya beberapa kegiatan seperti memberi salam, mengecek kesiapan siswa, menginformasikan tema, dan juga tahap-tahap pembelajaran berbasis HOTS.

Pada kegiatan inti tertulis adanya kegiatan seperti membaca teks, bertanya jawab, mengamati gambar, menuliskan laporan hasil pengamatan, membaca laporan, mencontohkan gerakan, pemberian penguatan serta motivasi.

Pada kegiatan ini tercantum tahapan membuat kesimpulan secara bersama-sama, memberikan kesempatan pada peserta didik untuk menyampaikan pendapatnya dan evaluasi.

remedial,dan pengayaan

Teknik penilaian yang terdapat pada RPP adalah, observasi, tes dan unjuk kerja.

Instrumen yang digunakan adalah tabel penilaian sikap, penilaian pengetahuan, dan penilaian keterampilan.

dan Pada kegiatan ini terdapat adanya tahapan mengulas kembali tentang materi yang sudah diajarkan.

Sumber belajar yang tertulis di RPP adalah tema 7 , subtema 4 , dan pembelajaran ke-4. Media yang digunakan gambar pada buku siswa.

Bedasarkan tabel diatas, komponen-komponen RPP yang dimiliki Ibu Sri Astutik sudah mengacu pada kurikulum 2013, hanya saja pada kegiatan pendahuluan tidak dijabarkan secara spesifik adanya ice braking. 
Penjabaran komponen dalam RPP berbasis HOTS belum begitu sempurna, hal ini sesuai dengan hasil wawancara yang dilakukan peneliti dengan guru sebagai berikut.

Peneliti : "Apakah di dalam RPP ini terdapat C4, C5, dan C6 yang sesuai dengan konsep pembelajaran berbasis HOTS?”

Guru : "Iya terdapat kegiatan meganalisis, megevaluasi dan mencipta. Tetapi masih dalam konteks yang sederhana”.

Peneliti : "Bagaimana Ibu menggambarkan pembelajaran berbasis HOTS dalam RPP?"

Guru

: "saya mempelajari silabus, buku siswa, dan buku guru terlebih dahulu baru kemudian saya melihat kompetensi inti dan kompetensi dasar, kemudaian menjabarkan indicator sesuai dengan tema/subtema. Dalam dalam pembelajaran saya mencoba untuk selalu memasukkan pemahaman akan cara berfikir tinggi HOTS.

Dari keseluruhan RPP Ibu Sri Astutik, sudah ,mendekati kata sempurna namun pada media pembelajaran kurang di jabarkan menganai media apa yang digunakan. Dan Ibu Sri astutik masih terpaku pada buku guru dan siswa sehingga tdak dapat berkreasi dengan model pembelajaran berbasis HOTS.

\section{Pelaksanaan pembelajaran}

Pada pelaksanaan pebelajaran Ibu Sri Astutik sudah berusaha melakukan sesuai dengan RPP yang dibuatnya, hal ini sesuai dengan hasil wawancara yang dilakukan peneliti.

Peneliti : “apakah proses pembelajaran yang dilaksanakan telah sesuai dengan RPP?”

Guru : " kami berusaha menyesuaikan, meski terkadang kami tidak melihat RPP lagi, tetapi untuk materi-materi yang agak berat kami selalu melihat RPP terlebih dahulu".

Berdasarkan hasil wawancara yang dilakukan peneliti, terdapat kendala yang membuat pembelajaran berbasis HOTS kurang maksimal dalam pelaksanaannya.Berikut hasil wawancaranya.

Peneliti :"apakah ada kendala yang ada pada saat pelaksanaan pembelajaran berbasis HOTS di kelas V ini?” 
Guru

: " kendalanya karena peserta didik baru mengenal lebih dalam mengenai pembelajaran berbasis HOTS, yang didalamnya membutuhkan pemikiran yang tinggi itu sebuah hal yang tidak mudah".

Peneliti : "lalu apa tindakan yang Ibu lakukan untuk megantasi kendala yang seperti ini?”

Guru : "dengan cara memberikan pengertian, pemberian contoh soal, dan memberikan soal-soal yang berbasis HOTs tiap harinya, meemang tidak semua siswa bisa betrfikir tinggi seperti itu tetapi tidak sedikit juga yang bisa itu lah kami katakan sudah cukup berhasil pembelajaran HOTS di kelas V ini”.

Dari analisis peneliti ditemukan bukan hanya satu kendala yang ada pada saat pembelajaran berbasis HOTS dilaksanakan, namun ada kendala yang menurut peneliti cukup mempengaruhi hasil belajar.Berikut hadil wawancara oleh peneliti dengan guru.

Peneliti : : " selain baru dalam mengenal pembelajaran berbasis HOTS, apa lagi yang menjadi kendala Ibu saat mengajar dikleas V ini?”

Guru : " waktu menjadi salah satu kendala yang cukup berpegaruh, karena berfikir tinggi untuk siswa kelas $\mathrm{V}$ membutuhkan banyak waktu sedangkan waktu yang di,iliki untuk belajar hanya 35 menit".

Dari hasil observasi dan wawancara dapat diketahui bahwa sekolah dan guru sudah berusaha menerapkan pembelajaran berbasis HOTS, meski masih banyak kendala. Selanjutnya, dari hasil observasi dan wawancara, ditemukan bahwa pelaksanaan pembelajaran berbasis HOTS yang di laksanakan oleh Ibu Sri Astutik di kelas V SDN 4 Muara Padang terdiri dari kegiatan utama yaitu, kegiatan pendahuluan, kegiatan inti, dan kegiatan penutup. Berikut ini gambaran dari pelaksanaan pembelajaran berbasis HOTS di kelas V SDN 4 Muara Padang. Berikut ini adalah tabel proses pembelajaran berbasis HOTS. 
Tabel 4. Proses Pembelajaran Berbasis HOTS

\begin{tabular}{|c|c|c|}
\hline & INDIKATOR & $\begin{array}{l}\text { DESKRIPSI HASIL } \\
\text { TEMUAN }\end{array}$ \\
\hline \multirow[t]{4}{*}{$\begin{array}{l}\text { KEGIATAN } \\
\text { PENDAHULUAN }\end{array}$} & $\begin{array}{l}\text { Guru mengkondisikan } \\
\text { siswa serta suasana } \\
\text { belajar yang } \\
\text { menyenagkan. } \\
\text { Guru } \\
\text { mendiskusikan } \\
\text { kompetensi yang } \\
\text { sudah dipelajari dan } \\
\text { dikemabngkan } \\
\text { sebeluumnya dengan } \\
\text { berkaitan yang } \\
\text { kompetensi yang } \\
\text { akan dipelajari dan } \\
\text { dikembangkan. }\end{array}$ & $\begin{array}{l}\text { Guru mempresensi siswa dan } \\
\text { mengkondisikan siswa untuk } \\
\text { mengikuti kegiatan belajar } \\
\text { mengajar. } \\
\text { Guru menyampaikan } \\
\text { kompetensi yang akan dipelajari. }\end{array}$ \\
\hline & $\begin{array}{l}\text { Guru akan } \\
\text { menyampaikan } \\
\text { kompetensi yang akan } \\
\text { dicapai dan manfaatnya } \\
\text { dalam kehidupan } \\
\text { sehari-hari. }\end{array}$ & $\begin{array}{l}\text { Guru meuampaikan kompetensi } \\
\text { yang akan dicapai pada hari itu. }\end{array}$ \\
\hline & $\begin{array}{l}\text { Guru menyampaikan } \\
\text { garis besar cangkupan } \\
\text { materi dan kegiatan } \\
\text { yang akan dilakukan. }\end{array}$ & $\begin{array}{l}\text { Guru menuliskan tentang materi } \\
\text { yang akan dipelajari, } \\
\text { menjelaskan kegiatan-kagiatan } \\
\text { dalam pembelajaran berbasis } \\
\text { HOTS. }\end{array}$ \\
\hline & $\begin{array}{l}\text { Guru menyampaikan } \\
\text { lingkup dan teknik } \\
\text { penilaian yang akan } \\
\text { dilakukan. }\end{array}$ & $\begin{array}{l}\text { Guru menyampaikan teknik } \\
\text { penilaian/evaluasi. }\end{array}$ \\
\hline \multirow[t]{2}{*}{ KEGIATAN INTI } & $\begin{array}{l}\text { Mengetahui (C1) } \\
\text { 1. Guru } \\
\text { menjelaskan } \\
\text { materi, agar } \\
\text { peserta didik } \\
\text { mengetahui } \\
\text { materi yang } \\
\text { akan di pelajari. } \\
\text { 2. Siswa dituntut } \\
\text { untuk } \\
\text { menginggat apa } \\
\text { yang } \\
\text { disampaikan } \\
\text { guru. }\end{array}$ & $\begin{array}{l}\text { Guru memberikan materi, lalu } \\
\text { peserta didik dituntut untuk } \\
\text { mengingat kembali pelajaran } \\
\text { yang telah di diajarkan minggu } \\
\text { lalu. Agar siswa dapat } \\
\text { menggunakan pengetahuannya } \\
\text { untuk menyelesaikan soal rutin } \\
\text { dan dapat menyelesaikan } \\
\text { masalah yang konteksnya } \\
\text { umum. }\end{array}$ \\
\hline & $\begin{array}{l}\text { Memahami (C2) } \\
\text { 1. Guru } \\
\text { memberikan } \\
\text { pemahaman }\end{array}$ & $\begin{array}{l}\text { Guru memberikan pemahaman } \\
\text { materi, dengan cara memberikan } \\
\text { contoh. Sedangkan peserta didik } \\
\text { setelah guru memberikan }\end{array}$ \\
\hline
\end{tabular}




\begin{tabular}{|c|c|c|}
\hline & INDIKATOR & $\begin{array}{l}\text { DESKRIPSI HASIL } \\
\text { TEMUAN }\end{array}$ \\
\hline & $\begin{array}{l}\text { konsep materi } \\
\text { dengan } \\
\text { memberikan } \\
\text { contoh yang } \\
\text { nyata. } \\
\text { 2. Siswa mampu } \\
\text { memmahami } \\
\text { materi dan } \\
\text { memberikan } \\
\text { contih. }\end{array}$ & $\begin{array}{llr}\text { pemhaman. } & \text { Peserta } & \text { didik } \\
\text { dituntut } & \text { untuk } & \text { dapat } \\
\text { memberikan } & \text { contoh } & \text { kembali. } \\
\text { Agar } & \text { siswa } & \text { dapat } \\
\text { menginterpretasikan } & \text { masalah } \\
\text { dan menyelesaikannya } & \text { dengan } \\
\text { rumus. } & & \end{array}$ \\
\hline & Menerapkan (C3) & $\begin{array}{l}\text { Guru meminta siswanya untuk } \\
\text { dapat menerapkan konsep yang } \\
\text { telah diberikan kepada siswa. } \\
\text { Dan peserta didik harus } \\
\text { melakukan dan mengaplikasikan } \\
\text { konsep tersebut. }\end{array}$ \\
\hline \multirow{6}{*}{$\begin{array}{l}\text { KEGIATAN } \\
\text { PENUTUP }\end{array}$} & Menganalisis (C4) & $\begin{array}{l}\text { Siswa diminta untuk } \\
\text { memindahkan konsep ke dalam } \\
\text { beberapa komponen dan } \\
\text { menghubungkan satu sama lain, } \\
\text { kemudian menghubungkannya } \\
\text { dengan dunia nyata. }\end{array}$ \\
\hline & Mengevaluasi (C5) & $\begin{array}{l}\text { Siswa megevaluasi sendiri materi } \\
\text { yang telah di pahami dan contoh } \\
\text { yang telah di buat. Serta guru } \\
\text { memberikan pengarahan. }\end{array}$ \\
\hline & Menciptakan (C6) & $\begin{array}{l}\text { Siswa mampu menciptakan } \\
\text { sesuatu yang baru, buah dari } \\
\text { pemahaman yang telah di } \\
\text { sampaikan oleh guru. }\end{array}$ \\
\hline & $\begin{array}{l}\text { Guru bersama siswa } \\
\text { membuat kesimpulan } \\
\text { secara bersama-sama. } \\
\text { Guru memberikan } \\
\text { umpan balik terhadap } \\
\text { proses pembelajaran. }\end{array}$ & \\
\hline & $\begin{array}{l}\text { Guru melakukan } \\
\text { penilaian }\end{array}$ & $\begin{array}{l}\text { Melakukan penilaian dengan tes } \\
\text { tertulis }\end{array}$ \\
\hline & $\begin{array}{l}\text { Guru merencanakan } \\
\text { kegiatan tindak lanjut } \\
\text { dalam bentuk } \\
\text { pembelajaran remedi, } \\
\text { program pengayaan, } \\
\text { layanan konseling dan } \\
\text { pemberian tugas. }\end{array}$ & \\
\hline
\end{tabular}




\section{Pembahasan}

\section{Kegiatan Pendahuluan}

Berdasarkan hasil observasi, kegiatan pemeblajaran yang dilakuakan Ibu Sri Astutik dalam kegiatan pendahuluan antara lain adalah mengkondisikan siswa dan suasana belajar yang cukup menyenagkan, mendiskusikan kompetensi yang sudah dipelajari, menyampaikan kompetensi yang akan dicapai, menyampaikan garis besar cakupan materi dan menyampaikan ruang lingkup dan teknik penilaian yang akan diberikan. Alasan guru melakukan kegiatan tersebut adalah karena guru agar peserta didik merasa nyaman dan senang saat pelajaran di mulai.

\section{Kegiatan Inti}

Berdasarkan hasil observasi dan wawancara, pelaksanaan kegiatan pembelajaran berbasis HOTS sudah cukup baik karena didalamnya sudah ada C1-C6. Berikut penjelasannya mengenai kegiatan pembelajaran dari mengetahui, memahami, menerapkan, menganalisis, mengevaluasi sampai menciptakan.

\section{Mengetahui (C1)}

Berdasarkan hasil observasi dapat ditemuakn bahwa guru memberikan informasi mengenai pelajaran, agar siswa dapat mengetahui serta menginggat kembali materi yang telah diberikan.Siswa dituntut untuk menginggat, menirukan dan mengulang pelajaran yang telah diberikan.

\section{Memahami (C2)}

Berdasarkan hasil observasi kegiatan memahami, yaitu siswa dapat mejelaskan ide/konsep serta dapat melaporkan konsep tersebut. Serta siswa sudah paham dengan apa yang mereka sampaikan. Seorang gurun juga harus mampu memberikan pemhaman yang baik dengan cara menggunakan metode-metode yang sesuai dengan materi yang akan di pelajari. Supaya siswa akan lebih mudah memahami pelaajaran tersebut.

\section{Mengaplikasi (C3)}

Berdasarkan hasil observasi tahapan mengaplikasi, yaitu kemampuan siswa untuk melakukan sesuatu dan mengaplikasikan konsep dalam situasi tertentu.Bisa dengan mencontohkan, mendemonstrasikan, mengilustrasikan serta mengoprasikan konsep tersebut.Dan peran guru disini yaitu hanya memberikan arahan dan petujuk terhadap siswa, biarkan siswa berkreasi terleebih dahlu.

\section{Menganalisis (C4)}


Berdasarkan hasil observasi kegiatan menganalisis, yaitu siswa diajarkan bagaimana menganalisis informasi yang masuk dan membagi-bagi serta siswa mampu mengenali dan membedakan faktor penyebab dan akibat dari sebuah skenario yang sulit.Bukan hanya itu siswa juga dapat merumuskan pertanyaan, yang timbul dari analisis mereka.

\section{Mengevaluasi (C5)}

Berdasarkan hasil observasi megananlisis adalah dimana siswa mampu mengambil keputusan sndiri dan mampu memberikan penilaian terhadap solusi, gagasan dan metodologi yang ada di konsep.Pada kegiatan mengevaluasi siswa diajarklan untuk membuat hhipotesis-hipotesis, mengkritik dan melakukan percobaan.

\section{Mencipta (C6)}

Berdasarkan hasil observasi kegiatan yang terakhir yaitu mencipta, maksudnya siswa dapat membuat generalisasi suatu ide atau cara pandangan terhadap sesuatu. Siswa juga dapat merencanakan suatu cara untuk menyelesaikan masalah serta dapat menciptakan sesuatu yang baru dari pemahaman konsep yang mereka lakukan. Disini guru berperan sangat penting, karena guru harus dapat mengarahkan peserta didiknya untuk mencapai C6 ini.

\section{Kegiatan Penutup}

Berdasarkan hasil observasi, kegiatan penutup dilakukan guru dan siswa adalah bersama-sama membuat kesimpulan terkait materi yang telah dipelajari.Siswa diminta untuk mengemukakan pendapatnya serta memberikan contoh yang berhubungan dengan materi tersebut. Guru membimbing siswa untuk menyimpulkan kembali materi tersebut. Penilaian yang dilakukan guru pada kegiatan penutup hanya terkait dengan kognitif, afektif dan psikomotorik, dan juga guru tidak menilai dalam proses pembelajaran. Namun guru menilai kemampuan peserta didik dengan memberikan soal. Berikut adalah wawancara peneliti dengan guru.

Peneliti : “apakah kegiatan penutup Ibu selalu memberi evaluasi, program pengayaan, ataupun kegiatan umpan balik?”

Guru : "kalau evalusai selalu kami lakukan setelah materi selesai, tetapi jika pengayaan ataupun umpan tidak selalu kami lakukan karena tidak adanya waktu yang cukup. Kami melakukan pengayaan dan umpan baik, jika hasil dari evaluasi tidak mecapai target yang ingin dicapai. 
Berdasarkan hasil wawancara, kegiatan penutup yang dilakukan guru yaitu dengan melakukan penarikan kesimpulan.Bukan hanya penarikan kesimpulan, namun juga guru melakukan evaluasi di akhir materi.

\section{Penilaian Pembelajaran Berbasis HOTS}

Hasil observasi yang ditemukan bahwa dalam penilaian pembelajaran yang dilakukan guru pada kelas V SDN 4 Muara Padang tidak melakukan penilaian pada proses pembelajara. Guru melakukan penilaian dari soal-soal tertulis yang terdapat dalam buku siswa. Sedangkan penilaian sikap dilakukan pada prosesbelajar mengajar, tatapi penilaian kognitif dilakukan dengan tes soal-soal.Hal ini sesuai dengan hasil wawancarapeneliti dan guru sepeti berikut ini.

Peneliti : "Bagaimana proses penilaian pembelajaran berbasis HOTS pada kelas V ini ya Bu?"

Guru : "Saya tidak pernah menilai kognitif peserta didik pada saat pembelajaran, tetapai saya memberikan soal-soal terlebih dahulu. Dan dengan begitu kita dapat mengetahui kemampuan peserta didik dalam memahami materi yang disampaikan, tetapi jika penilaian afektif saya menilai setiap kali pembelajaran dilaksanakan".

Dengan begitu, dapat simpulkan bahwa guru meemiliki berbagai macam sistem penilaian, beda guru beda cara danmetodenya. Pada kelas V SDN 4 Muara Padang ini, guru kelasnya memberikan penilaian afektif setiap pertemuan pembelajaran dan nilai kognitif dengan cara memberikan soal-soal terlebih dahulu.

\section{Kendala-Kendala dalam Proses Pembelajaran}

Dari hasil observasi terdapat beberapa kendala yang dihadapi oleh guru dan siswa. Kendala yang dihadapi guru adalah terbatasnya waktu, pemahaman yang kurang tetang pembelajaran berbasis HOTS karena sekolah baru menggunakan kurikulum 2013 pada dua tahun terakhir ini, siswa yang belum terbiasa dengan soal-soal HOTS, pemahaman guru dengan pembelajaran berbasis HOTS masih sangat kurang serta kurangnya fasilitas dalam pembelajaran berbasis HOTS, misalnya buku, dan media pembelajaran. Hal ini sesuai dengan hasil wawancara peneliti dengan guru:

Peneliti : "Kendala atau masalah apa yang Ibu hadapi saat melaksanakan pembelajaran berbasis HOTS ini di kelas V?” 
Guru

: "Kendalanya ada yaitu kurangnya waktu karena alokasi waktu hanya 35 menit sedangkan pada pembelajaran berbasis HOTS ini siswa dituntut untuk berfikir tinggi yang memerlukan waktu yang panjang”.

Peneliti :'Selain waktu adakah lagi kendala yang dihadapi Ibu?"

Guru : "kendala yang sangat berpengaruh adalah peserta didik itu sendiri, karena sekolah ini baru dua tahun menggunakan kurikulum 2013 yang berbasis HOTS, jadi peserta didik mulai mengenal pembelajaran HOTS pada kelas 4 semester akhir dan juga buku pelajaran serta media yang kurang memadai. Itu yang membuat siswa menjadi lambat dalam proses belajar berbasis HOTS”.

Jadi, dapat disimpulkan bahwa kendala pada pembelajaran berbasis HOTS di SDN 4 Muara Padang adalah, waktu, siswa yang kurang memahami pembelajaran HOTS, media dan buku pelajaran.

\section{KESIMPULAN}

Berdasarkan hasil pembahasan, maka penelitian ini dapat disimpulkan bahwa di SDN 4 Muara Padang, proses pembelajaran erbasis HOTS, sudah hampir terlaksana dengan baik. Dilihat dari sudah adanya RPP ssampai dengan pelaksanaan pembelajaran yang sudah menyesuaikan RPP yang dibuat. Belum sempurnanya proses pembelajaran berbasis HOTS ini karena adanya beberapa kendala, yaitu kurangnya alokasi waktu untuk belajar, siswa yang belum terbiasa berfikir tingkat tinggi karena terbilang cukup baru mengenal pembelajaran HOTS dari yang awalnya pembelajaran dengan menggunakan kurikulum 2006 dan baru dua tahun beralih ke kurikulum 2013, dan kendala yang terakhir yaitu kurangnya buku pelajaran serta media pembelajaran yang mendukung pembelajaran berbasis HOTS.

\section{SARAN}

Saran dari penulis, akan jauh lebih baik jika pelaksanaan pembelajaran berbasis HOTS yang ada di SDN 4 Muara Padang, lebih menekankan pada proses pemahaman peserta didiknya. Dan juga dari pihak kepala sekolahn dan guru dapat memfasilitasi peserta didiknya dengan alat serta media yang dibutuhkan. Butuhnya pengawasan dan bimbingan yang ekstra ketet dari pengawas sekolah dan kepala sekolah agar pelaksanaan pembelajaran berbasis HOTS dapat berjalan dengan baik. Bukan hanya itu, pemahaman konsep yang cukup harus dilakukan seorang guru kepada peserta didiknya agar pelaksanaan pembelajaran berbasis HOTS terealisasi dengan baik sesuai dengan kurikulum 2013. 


\section{REFERENSI}

Eko Siswanto, Tatang Yuli.(2008). Model Pembelajaran Matematika Berbasis pengajuan dan Pemecahan masalah untuk Meningkatkan Kemampuan Berfikir Kreatif. Surabaya: Unesa university Press.

Kemendikbud. (2017). Modul Penyusunan HOTS. Jakarta: Direktort Jendral Pendidikan Dasar dan Menegah Departemen pendidikan dan Kebudayaan.

Marpaung, Y dan Suparno, paul. (1987). Sumbangan Pikiran terhadap Pendidikan Matematika dan Fisika. Yogyakarta: MIPA IKIP sanata Dharma.

Miles, B. Mathew dan Michael Humberman. (1992). Analisis Data Kualitatif Buku Sumber Tentang Metode-metode Baru. Jakarta: UIP

Saputra, Hatta. (2016). Pengembangan Mutu Pendidikan Menuju Era Global: Penguatan Mutu pembelajaran dan Penerapan HOTS (Higher Order Thingking Skill). Bandung: SMILE's Publishing.

Suyitno, Hardi. (2008). Hubungan antara Bahasa dengan Logika dan matematika Menurut pemikiran Wittgenstein. Jurnal Humaniora Vol. 20. Surabaya: UNAIR.

Ghandi, I. N, dkk. (2015). Influences of critical thingking dispotision on critical thingking skiils of undergraduate students at a Malaysia Public University. Journal of Educational Research and Reveiws. Vol. 3(2), pp. 23-31. Diakses pada tanggal14 September pukul 19:33 WIB.

R, Kustijono dan Wiwin, EHM. (2014). Pandangan Guru terhadap Pelaksanaan Kurikulum 2013 dalam Pembelajaran Fisika SMK Kota Surabaya. Jurnal Pendidikan Fisika dan Aplikasinya (JPFA) ISSN: 2087-9946 Vol 4 No 1. Di akses pada tanggal 20 September 2019 pukul 14:30 WIB. 